opments in Parkinson's disease. Florham Park, NJ: Macmillan, 1987: 153-63.

. for mental disorders (DSM-III-R). 3rd ed (rev). for mental disorders (DSM

13 Spitzer RL, Williams JBW, Gibbon M, First MB. The structured clinical interview for DSM-III-R (SCID). I: history, rationale, and description. Arch Gen Psychiatry 1992;49:624-9.

14 Wing JK, Cooper E, Sartorius N. Measurements and classification of psychiatric symptoms. Cambridge: Cambridge University Press, 1974

15 Spitzer R, Endicott J, Robins E. Research diagnostic criteria (RDC) for a group of functional disorders. New York: Biometrics Research Division, New York Psychiatric Institute, 1975.

16 Hamilton MA. A rating scale for depression. 7 Neurol Neurosurg Psychiatry 1960;23:56-62.
17 Hamilton MA. The assessment of anxiety states by rating. Br f Med Psychol 1959;32:50-5.

18 Folstein MF, Folstein SE, McHugh PR. Mini-Mental state: a practical method for grading the cognitive state of patients for the clinician. $\mathcal{F}$ Psychiat Res 1975;12: of patients

19 Granger CV, Hamilton BB, Kayton R. Guide for use of the uniform data set for medical rehabilitation. Buffalo, NY: Uniform Data System for Medical Rehabilitation, 1986

20 Starr LB, Robinson RG, Price TR. Reliability, validity and clinical utility of the Social Functioning Exam in the assessment of stroke patients. Exp Aging Res 1983;9: 101-10.

21 Hughes AJ, Lees AJ, Stern GM. Apomorphine test to predict responsiveness in parkinsonian syndromes. Lancet 1990; ii:32-4.

22 Webster DD. Critical analysis of the disability in Parkinson's disease. Modern Treatment 1968;5:257-82.

\section{Notes on tetanus (lockjaw)}

Tetanus (Greek tetanos, derived from teinein to stretch) appears through the ages in military medicine. Slapping infected dung on to the newborn umbilical cord caused tetanus neonatorum or "trismus nascentium" to be rampant in the West Indies and Africa. Osler's textbook describes the "eight days sickness" caused by umbilical sepsis, which in St Kilda killed 84 of 125 children within a fortnight of birth. ${ }^{1}$ In the first world war it occurred in 1.47 per 1000 of the British wounded, and in 12.5 per 1000 in the Peninsular campaign. ${ }^{2}$

In an earlier battle, Sir Charles Bell's famous war illustration portrays tetanus in a soldier during Sir John Moore's retreat to Corunna.

Risus sardonicus hails from the sneering grin thought to resemble the effect of a Sardinian rununculus, which on being chewed contorted the face of the eater. The anaerobic bacillus Clostridium tetani was discovered by Nicolaier in 1885. In 1889 Koch's pupil Kitasato obtained the bacillus of tetanus in pure culture and conveyed the disease to animals.

Antitoxin was quickly recognised by Thomas Clifford Allbutt (System of Medicine 1896;1:237): "The diphtheria and tetanus antitoxins act directly on the toxins." Antitetanus serum was in general use before the first world war, but the dose was variable. And the intrathecal, intravenous, or intramuscular routes each had its proponents. The mortality was still between $37 \%$ and $50 \%$.

Ancient descriptions are impressive:

\section{Hippocrates}

"The master of a large ship mashed the index finger of his right hand with the anchor. Seven days later a somewhat foul discharge appeared; then trouble with his tongue-he complained he could not speak properly. The presence of tetanus was diagnosed, his jaws became pressed together, his teeth were locked, then symptoms appeared in his neck; on the third day opisthotonos appeared with sweating. Six days after the diagnosis was made he died"

In the Aphorisms (c $380 \mathrm{BC}$ ): ${ }^{4}$ section V 2, "Spasm supervening on a wound is fatal." And section V 6, "Such persons as are seized with tetanus either die within four days, or if they pass these they recover".

\section{Aretaeus}

An inhabitant of Cappadocia (1st century AD), an ancient kingdom of Asia Minor, Aretaeus left this wonderful characterisation: ${ }^{5}$

"Tetanus in all its varieties, is a spasm of an exceedingly painful nature, very swift to prove fatal, but neither easy to be removed.... There are three forms of the convulsions, namely in a straight line, backwards and forwards ... there is tension in a straight line of the whole body, which is unbent and inflexible....

Opisthotonos bends the patient backward, like a bow, so that the reflected head is lodged between the shoulder-blades; the throat protrudes; the jaw sometimes gapes, ... respirations stertorous; the belly and chest prominent ... the abdomen stretched, and resonant if tapped; the arms strongly bent back in a state of extension; the legs and thighs are bent together....

The causes of these complaints are many; for some are apt to supervene on the wound of a membrane, or of muscles,.... And women also suffer from this spasm after abortion; and in this case they seldom recover . ...

In all of these varieties then, there is pain and tension of the tendons and spine, and of the muscles connected with the jaws and cheek; for they fasten the lower jaw to the upper, so that it cannot easily be separated even with levers or a wedge. But if one by forcibly separating the teeth, pour in some liquid the patients do not drink it but squirt it out . . . .

But if they are bent forward (Emprosthotonos), they are protuberant at the back, the loins being extruded in a line with the back, the whole spine being straight; . . . the lower jaw fixed on the breast bone; the hands clasped together, the lower extremities extended; pains intense; the voice altogether dolorous. Should the mischief then seize the chest and respiratory organs, it readily frees the patient from life...

"An inhuman calamity! an unseemly sight! ... But neither can the physician, furnish any assistance, as regards life, relief from pain or from deformity." J M S PEARCE
304 Beverley Road, Anlaby,
Hull HU1O $7 B G, U K$

1 Osler W. Principles and practice of medicine. 1898. 2 Official history of the war (Pathology, 1923), cited by Wilson SAK, In: Neurology. London: Arnold, 1940:626. Beck T. Hippokrates Erkenntnisse. Jena: Diedrichs, 1907:132. 3 Beck T. Hippokrates Erkenntnisse. Jena: Diedrichs, 1907:132. Adams F. Aphorisms. In: The genuine works of Hippocrate
Vol 2. London: The Sydenham Society 1849:737-8.

Vol 2. London: The Sydenham Society 1849:737-8. Adams F. The extant works of Aretaeus, the Cappadocian.
Edited and translated, London: The Sydenham Society, Edited and
1856:253. 